\title{
Development of enteric submicron particle formulation of papain for oral delivery
}

This article was published in the following Dove Press journal:

International Journal of Nanomedicine

22 September 2011

Number of times this article has been viewed

\author{
Manu Sharma' \\ Vinay Sharma ${ }^{2}$ \\ Amulya K Panda ${ }^{3}$ \\ Dipak K Majumdar ${ }^{4}$ \\ 'Department of Pharmacy, Banasthali \\ Vidhyapith, Banasthali, India; \\ ${ }^{2}$ Department of Bioscience and \\ Biotechnology, Banasthali Vidhyapith, \\ Banasthali, India; ${ }^{3}$ National Institute \\ of Immunology, Aruna Asaf Ali Marg, \\ New Delhi, India; ${ }^{4}$ Department of \\ Pharmaceutics, Delhi Institute of \\ Pharmaceutical Sciences and Research, \\ University of Delhi, New Delhi, India
}

Correspondence: Dipak K Majumdar Department of Pharmaceutics, Delhi Institute of Pharmaceutical Sciences and Research, University of Delhi, Pushp Vihar, Sector III, New Delhi II0017, India $\mathrm{Tel}+9$ I II 25847043

Fax +91 II 29554503

Email dkmajumdaar@yahoo.com
Background: Particulate systems have received increasing attention for oral delivery of biomolecules. The objective of the present study was to prepare submicron particulate formulations of papain for $\mathrm{pH}$-dependent site-specific release using $\mathrm{pH}$-sensitive polymers.

Methods: Enteric submicron particle formulations of papain were prepared by w/o/w emulsion solvent evaporation using hydroxypropyl methylcellulose phthalate (HPMCP), Eudragit L100, and Eudragit S100, to avoid gastric inactivation of papain.

Results: Smaller internal and external aqueous phase volumes provided maximum encapsulation efficiency $(75.58 \%-82.35 \%)$, the smallest particle size $(665.6-692.4 \mathrm{~nm})$, and $25 \%-30 \%$ loss of enzyme activity. Release studies in $0.1 \mathrm{~N} \mathrm{HCl}$ confirmed the gastroresistance of the formulations. The anionic submicron particles aggregated in $0.1 \mathrm{~N} \mathrm{HCl}$ (ie, gastric $\mathrm{pH} 1.2$ ) due to protonation of carboxylic groups in the enteric polymer. Aggregates $<500 \mu \mathrm{m}$ size would not impede gastric emptying. However, at $\mathrm{pH}>5.0$ (duodenal $\mathrm{pH}$ ), the submicron particles showed deaggregation due to restoration of surface charge. HPMCP submicron particles facilitated almost complete release of papain within 30 minutes at pH 6.0, while Eudragit L100 and Eudragit S100 particles released $88.82 \%$ and $53.00 \%$ of papain at $\mathrm{pH} 6.8$ and $\mathrm{pH} 7.4$, respectively, according to the Korsmeyer-Peppas equation. Sodium dodecyl sulfate polyacrylamide gel electrophoresis and fluorescence spectroscopy confirmed that the structural integrity of the enzyme was maintained during encapsulation. Fourier transform infrared spectroscopy revealed entrapment of the enzyme, with powder x-ray diffraction and differential scanning calorimetry indicating an amorphous character, and scanning electron microscopy showing that the submicron particles had a spherical shape.

Conclusion: In simulated gastrointestinal pH conditions, the HPMCP, Eudragit L100, and Eudragit S100 submicron particles showed good digestion of paneer and milk protein, and could serve as potential carriers for oral enzyme delivery. Stability studies indicated that formulations with approximately $6 \%$ overage would ensure a two-year shelf-life at room temperature.

Keywords: papain, hydroxypropyl methylcellulose phthalate, Eudragit L100, Eudragit S100, zeta potential

\section{Introduction}

Dietary proteins are essential for growth, repair, and regulation of homeostasis. However, many people are intolerant of such foods, which includes baked beans, bean soup, soybean, and meat. This intolerance can lead to uncomfortable and embarrassing symptoms, such as flatulence, belching, diarrhea/constipation, malnutrition, food allergies, anemia, undigested food in stool, chronic intestinal parasites, and abnormal flora. These symptoms usually occur during achlorhydria and/or pancreatin insufficiency. ${ }^{1,2}$ Therefore, the need for a protein-digesting supplement arises. ${ }^{3}$ Nowadays, the demand 
for digestive aids has increased, but the supply of pepsin (prepared from hog mucosa) has decreased. Thus, plant-derived proteases like papain can be used because there is no scarcity of supply. ${ }^{4}$ Papain is a food-grade, highly active endolytic cysteine protease (EC 3.4.22.2) derived from Carica papaya. Its broad substrate specificity and ability to hydrolyze small peptides as well as large proteins make papain an ideal enzymatic supplement. ${ }^{5}$ However, the most critical challenge in oral delivery of papain is to preserve the formulation during its passage through the stomach without denaturation. ${ }^{6}$

The key to the success of digestive proteins as pharmaceuticals is to have in place an efficient site-specific $\mathrm{pH}$-dependent drug delivery system that allows the protein to gain access to the target site (intestine) at the right time and for an appropriate duration. $\mathrm{pH}$-sensitive polymers (water-insoluble at low $\mathrm{pH}$, water-soluble at high $\mathrm{pH}$ ) are of particular interest because the drug release rate can be controlled by the $\mathrm{pH}$ of the environment. ${ }^{7}$ The commonly used $\mathrm{pH}$-sensitive enteric polymers are hydroxypropyl methylcellulose phthalate (HPMCP) and acrylic copolymers, ie, Eudragit L100 and Eudragit S100. ${ }^{8}$ These polymers, when used as coating materials, produce films that are resistant to gastric fluid. HPMCP dissolves at a lower $\mathrm{pH}(5.0-5.5)$ than acrylic copolymers, and this solubility characteristic can be utilized for delivery of drug into the duodenum. ${ }^{9,10}$ Acrylic polymers, eg, Eudragit (Röhm Pharma, Darmstadt, Germany), a copolymer of methacrylic acid and its esters, have a special place in $\mathrm{pH}$-dependent site-specific delivery of drugs. ${ }^{11}$ Eudragit L100 dissolves in the $\mathrm{pH}$ range of 6.0-6.5, which ensures drug release in the distal small intestine (ileum), while Eudragit S100 dissolves at $\mathrm{pH}>7.0$ and releases the drug into the colon. An enteric formulation of papain is more rational than immediate-release commercial papain products because the former would protect the acid-labile enzyme from gastric $\mathrm{pH}$ and deliver it to the site of action, ie, the small intestine. Enteric-coated microspheres of pancreatin $1.0-1.2 \mathrm{~mm}$ in diameter show $25 \%$ higher therapeutic effectiveness compared with 1.8-2.0 mm microspheres. ${ }^{12,13}$ Because microspheres with a size greater than $1.2 \mathrm{~mm}$ pass through the stomach at a slower rate than a meal, the same would be less efficacious in restoring enzyme activity than preparations with smaller sphere sizes. ${ }^{14}$ Therefore, the design of particulate systems has received increasing attention for oral delivery of these biomolecules. ${ }^{15}$ The high surface area to volume ratios of nanospheres/submicron particles often cause a fast initial release, resulting in a high burst within a short duration. ${ }^{16,17}$ Nanospheres are well suited for target-specific drug delivery because of their small size, ${ }^{18,19}$ and a relatively rapid release may be preferable for certain purposes, such as for delivery of digestive proteins. Thus, the objective of the present study was to prepare submicron particulate formulations of papain for $\mathrm{pH}$-dependent sitespecific release using $\mathrm{pH}$-sensitive polymers, ie, HPMCP, Eudragit L100, and Eudragit S100.

\section{Materials and methods Materials}

HPMCP (molecular weight $45 \mathrm{kDa}$ ) and the methacrylic acid copolymers, Eudragit L100 and Eudragit S100 (average molecular weight $135 \mathrm{kDa}$ ), were gifted by Jubilant Organosys, Noida, India. Potassium dihydrogen phosphate, sodium hydroxide, and hydrochloric acid (Qualigens Fine Chemicals, Mumbai, India), papain (source C. papaya), casein, tyrosine, and trichloroacetic acid (98.0\%) were obtained from Himedia Laboratories Pvt Ltd, Mumbai, India, and were used as received. Disodium ethylenediamine tetra-acetate $(99.5 \%)$, cysteine hydrochloride (99.0\%), citric acid (98.0\%), polyvinyl alcohol, and lactose were purchased from SD FineChem Ltd, Mumbai, India. A micro $\mathrm{BCA}^{\mathrm{TM}}$ protein assay kit (Pierce, Rockford, IL) was obtained from ThermoScientific, Karnataka, India. Ethanol, dichloromethane, and isopropanol were obtained from Merck, Darmstadt, Germany. Saras paneer (a milk solid containing per $100.0 \mathrm{~g}$ : fat [24.0 g], protein [20.0 g], carbohydrates [3.6 g], calcium [400.0 mg], phosphorus [200.0 mg], and vitamins B [0.05 mg] and A [120.0 $\mu \mathrm{g}]$ ) and Saras toned milk were obtained from Jaipur Zila Dugdh Utpadak Sahakari Sangh Ltd, Rajasthan, India. All other chemicals and solvents were of analytical grade and used without further purification. Double-distilled water was used throughout the study.

\section{Preparation of submicron particles}

Papain-loaded submicron particles were prepared using a double-emulsion solvent evaporation technique. An aqueous solution of papain at a concentration of $141.06 \mathrm{mg} / \mathrm{mL}$ was prepared. The internal aqueous phase $\left(\mathrm{W}_{1}, 0.4,0.2,0.1\right.$, $0.05 \mathrm{~mL}$, Table 1) containing papain, $3 \% \mathrm{v} / \mathrm{v}$ polysorbate 20 (dispersing agent), and $0.16 \% \mathrm{w} / \mathrm{v}$ lactose as a cryoprotectant was emulsified with $5 \mathrm{~mL}$ of organic phase for one minute using an ultrasonic disruptor ( $30 \mathrm{~W}$ output power, $40 \%$ duty cycle, Branson Sonifier ${ }^{\circledR} 450$, Danbury, CT). Temperature was maintained at $4^{\circ} \mathrm{C}$, using an ice bath during emulsification. The organic phase consisted of $200 \mathrm{mg}$ of polymer (HPMCP, Eudragit L100, or Eudragit S100) in $5 \mathrm{~mL}$ of a mixed solvent system of dichloromethane, ethanol, and isopropanol in a ratio of $5: 6: 4 .{ }^{20}$ The resulting primary emulsion ( $\mathrm{W}_{1}$ /organic phase) was added drop by drop to the external aqueous phase $\left(\mathrm{W}_{2}\right.$, 50,25 , or $16 \mathrm{~mL}$, Table 1 ) of $1 \% \mathrm{w} / \mathrm{v}$ polyvinyl alcohol and 
Table I Different batches of SPs prepared with HPMCP, Eudragit L 100 and Eudragit S 100 polymer

\begin{tabular}{|c|c|c|c|c|c|}
\hline Polymer & Formulation code & Volume of IAP $\left(W_{1}\right) \mathrm{mL}$ & $\mathbf{W}_{1}: \mathbf{O}$ & Volume of EAP $\left(\mathrm{W}_{2}\right) \mathrm{mL}$ & $\mathbf{O}: \mathrm{W}_{2}$ \\
\hline \multirow[t]{6}{*}{ HPMCP } & $\mathrm{HS}_{1}$ & 0.4 & $\mathrm{I}: 12.5$ & 16 & $1: 3.2$ \\
\hline & $\mathrm{HS}_{2}$ & 0.2 & $\mathrm{I}: 25$ & 16 & $1: 3.2$ \\
\hline & $\mathrm{HS}_{3}$ & 0.1 & $1: 50$ & 16 & $1: 3.2$ \\
\hline & $\mathrm{HS}_{4}$ & 0.05 & $\mathrm{I}: 100$ & 16 & $1: 3.2$ \\
\hline & $\mathrm{HS}_{5}$ & 0.05 & $\mathrm{I}: 100$ & 25 & $\mathrm{I}: 5$ \\
\hline & $\mathrm{HS}_{6}$ & 0.05 & $\mathrm{I}: 100$ & 50 & $1: 10$ \\
\hline \multirow[t]{6}{*}{ Eudragit L I00 } & $\mathrm{LS}_{1}$ & 0.4 & $\mathrm{I}: 12.5$ & 16 & 1:3.2 \\
\hline & $\mathrm{LS}_{2}$ & 0.2 & $\mathrm{I}: 25$ & 16 & $1: 3.2$ \\
\hline & $\mathrm{LS}_{3}$ & 0.1 & $1: 50$ & 16 & 1:3.2 \\
\hline & $\mathrm{LS}_{4}$ & 0.05 & $1: 100$ & 16 & 1:3.2 \\
\hline & $\mathrm{LS}_{5}$ & 0.05 & $\mathrm{I}: 100$ & 25 & $\mathrm{I}: 5$ \\
\hline & $\mathrm{LS}_{6}$ & 0.05 & $1: 100$ & 50 & $1: 10$ \\
\hline \multirow[t]{6}{*}{ Eudragit S 100} & $\mathrm{SS}_{1}$ & 0.4 & $\mathrm{I}: 12.5$ & 16 & |:3.2 \\
\hline & $\mathrm{SS}_{2}$ & 0.2 & $1: 25$ & 16 & 1:3.2 \\
\hline & $\mathrm{SS}_{3}$ & 0.1 & $\mathrm{I}: 50$ & 16 & |:3.2 \\
\hline & $\mathrm{SS}_{4}$ & 0.05 & $1: 100$ & 16 & |:3.2 \\
\hline & $\mathrm{SS}_{5}$ & 0.05 & $1: 100$ & 25 & I:5 \\
\hline & $\mathrm{SS}_{6}$ & 0.05 & $\mathrm{I}: 100$ & 50 & $1: 10$ \\
\hline
\end{tabular}

Abbreviations: SPs, Submicron particles; IAP, Internal aqueous phase; O, Organic phase; EAP, External aqueous phase; HPMCP, Hydroxypropyl methylcellulose phthalate.

$1.6 \% \mathrm{w} / \mathrm{v}$ lactose solution. The aqueous polyvinyl alcohol solution acted as an emulsion stabilizer. Emulsification was continued using an ultrasonic disruptor $(30 \mathrm{~W}$ output power, $40 \%$ duty cycle, Branson Sonifier) for two minutes to form a multiple emulsion $\left(\mathrm{W}_{1} /\right.$ organic phase $\left./ \mathrm{W}_{2}\right)$ at $4^{\circ} \mathrm{C}$ in an ice bath. The resulting $\mathrm{W}_{1} /$ organic phase $/ \mathrm{W}_{2}$ emulsion was stirred at room temperature for 16-18 hours with a magnetic stirrer to allow the solvent to evaporate. The submicron particles were collected and washed three times with distilled water by centrifugation at $55,000 \mathrm{~g}$ for 25 minutes at $4^{\circ} \mathrm{C}$. The submicron particles were resuspended in distilled water and lyophilized for 24 hours. The final product was stored in a desiccator at $25^{\circ} \mathrm{C}$. Different formulations prepared by varying the internal aqueous:organic:external aqueous phase ratio as well as polymer were coded as shown in Table 1 . The optimized formulation prepared with $50 \mu \mathrm{L}$ internal aqueous: $5 \mathrm{~mL}$ organic: $16 \mathrm{~mL}$ external aqueous phase (ie, $\mathrm{HS}_{4}, \mathrm{LS}_{4}, \mathrm{SS}_{4}$ ) was subjected to further investigation.

\section{Characterization of submicron particles} Enzyme Assay

The proteolytic activity of papain was estimated using a modified casein digestion method (USP XXVII) in the presence of cysteine hydrochloride. An appropriately diluted standard papain solution in phosphate-cysteine disodium ethylenediamine tetra-acetate buffer was added to $5 \mathrm{~mL}$ of buffered $1 \%$ casein substrate $(\mathrm{pH} 6.0 \pm 0.1)$. After incubation at $37^{\circ} \mathrm{C}$ for 20 minutes in a shaking water bath, the reaction was stopped by the addition of $3 \mathrm{~mL}$ of $30 \% \mathrm{w} / \mathrm{v}$ trichloroacetic acid solution. The tubes were allowed to stand for 30-40 minutes at $40^{\circ} \mathrm{C}$ in a water bath to allow complete coagulation of the precipitated protein. Thereafter, the supernatant containing the digested amino acids was filtered through Whatman filter paper No 42 by discarding the first $3 \mathrm{~mL}$ of filtrate. The absorbance of the filtrate was measured at $280 \mathrm{~nm}$ using an ultraviolet-visible spectrophotometer (LabIndia ${ }^{\circledR}$ UV $3000^{+}$, Mumbai, India) against the standard plot of tyrosine absorbance versus tyrosine concentration $(\mu \mathrm{g} / \mathrm{mL})$. Papain activity was expressed in terms of casein digestion units (CDU). A CDU is the $\mu \mathrm{g}$ of tyrosine liberated per minute by $1 \mathrm{mg}$ of enzyme under assay conditions.

\section{Estimation of encapsulation efficiency}

Ten milligrams of submicron particles were weighed accurately and dissolved in $1 \mathrm{~mL}$ of phosphate buffer ( $\mathrm{pH}$ 7.4). The resulting solution was analyzed for papain content by measuring absorbance in an enzyme-linked immunosorbent assay at $540 \mathrm{~nm}$ using a micro BCA protein assay kit for protein estimation. Results were expressed as the mean \pm standard error of three experiments. Encapsulation efficiency was calculated as

$$
\begin{gathered}
\text { Actual loading }(\%)=\frac{\mathrm{mg} \text { of encapsulated enzyme }}{100 \mathrm{mg} \text { submicron particle }} \\
\text { Encapsulation efficiency }(\%) \\
=\frac{\text { Actual enzyme loaded }}{\text { Theoretical enzyme loading }} \times 100
\end{gathered}
$$




\section{Enteric nature of submicron particles}

This test was performed to determine the extent of drug release in the acidic environment of the stomach (ie, $\mathrm{pH} 1-3$ ). An accurately weighed sample $(n=3)$ of papain-loaded HPMCP, Eudragit L100, or Eudragit S100 submicron particles equivalent to $10 \mathrm{mg}$ of papain was introduced into $20 \mathrm{~mL}$ of $0.1 \mathrm{~N} \mathrm{HCl}$ equilibrated at $37^{\circ} \mathrm{C} \pm 0.5^{\circ} \mathrm{C}$ in a shaking water bath at 100 shakes per minute. Samples were withdrawn after 120 minutes and the protein content was determined using a micro BCA protein assay kit.

\section{In vitro drug release}

In vitro release of papain from the enteric-coated submicron particles was recorded to determine the effect of $\mathrm{pH}$ on drug release. Accurately weighed samples $(n=3)$ equivalent to about $10 \mathrm{mg}$ of papain were transferred to $20 \mathrm{~mL}$ of prewarmed dissolution media $(\mathrm{pH} 6.0,6.8$, or 7.4 phosphate buffer), maintained at $37^{\circ} \mathrm{C} \pm 0.5^{\circ} \mathrm{C}$ in a shaking water bath at 100 shakes per minute. At predetermined time intervals, a $1 \mathrm{~mL}$ sample was withdrawn followed by replacement of the withdrawn volume by fresh phosphate buffer. Enzyme content was estimated using a micro BCA protein assay kit of protein estimation to confirm the integrity of the protein molecule. Results were expressed as the mean \pm standard error of three experiments.

\section{Release kinetics}

The mechanism of drug release was investigated by fitting the drug release data into zero order, first order, Higuchi, and Korsmeyer-Peppas equations. The goodness of fit of drug release was evaluated by the regression coefficient $\left(\mathrm{R}^{2}\right)$ value.

\section{Measurement of particle size and zeta potential}

Freeze-dried submicron particles were dispersed in water after treatment in an ultrasonic disperser (Seishin Enterprise Co Ltd, Shibuya-Ku, Japan) for 20 seconds. The $\mathrm{z}$ average mean diameter, zeta potential, and polydispersity index of the papain-loaded submicron particles in an aqueous dispersion were measured by a dynamic light scattering method using a Zetasizer Nano ZS (Malvern Instruments, Worcestershire, UK). Each value quoted was the average of determinations on three independent samples. Change in the behavior of submicron particles with a change in the $\mathrm{pH}$, ie, $\mathrm{pH} 1.2-5.3$ of the release media was analyzed using an optical imaging system (Nikon Eclipse TS100, Nikon, Tokyo, Japan), equipped with a Sony camera (Hyper HAD model
SSC-DC38DP, Elvetec, Templemars, France) and Optimas 6.0 software (Media Cybernetics, Silver Spring, MD).

\section{Digestion of paneer and milk protein}

Paneer or a milk sample containing an amount equivalent to $450 \mathrm{mg}$ casein was taken for determining the proteolytic activity of papain. Paneer $2.25 \mathrm{~g}$ passed through a sieve no 22 or toned milk $17.14 \mathrm{~mL}$ was mixed with $20 \mathrm{~mL}$ of $0.1 \mathrm{~N} \mathrm{HCl}$ and an optimized formulation of enteric submicron particles $\left(\mathrm{HS}_{4}, \mathrm{LS}_{4}\right.$, or $\left.\mathrm{SS}_{4}\right)$ equivalent to $1.0 \mathrm{mg}$ of papain was added and the mixture was maintained at $37^{\circ} \mathrm{C} \pm 0.5^{\circ} \mathrm{C}$ in a shaking water bath at 100 shakes per minute for two hours followed by an increase in the $\mathrm{pH}$ to 6.0 by addition of disodium hydrogen phosphate and kept for two hours. Subsequently the $\mathrm{pH}$ was raised from $\mathrm{pH} 6.0$ to 6.8 and kept for two hours, followed by a further increase in $\mathrm{pH}$ from $\mathrm{pH} 6.8$ to 7.4 and maintained for two hours. At predetermined time intervals, a $1 \mathrm{~mL}$ sample was withdrawn followed by replacement of the withdrawn volume by fresh phosphate buffer. Samples were centrifuged at 17,000 rpm for 30 minutes and the supernatant was estimated for tyrosine content by a modified casein digestion method (USP XXVII).

\section{SDS-PAGE}

Sodium dodecyl sulfate polyacrylamide gel electrophoresis (SDS-PAGE) of papain and optimized papain-loaded submicron particles $\left(\mathrm{HS}_{4}, \mathrm{LS}_{4}\right.$, and $\left.\mathrm{SS}_{4}\right)$ was performed according to the method of Laemmli on a slab gel containing $12 \%$ running gel and 5\% stacking gel. ${ }^{21}$ Vertical minigel apparatus (Pharmacia, GE Healthcare, Uppsala, Sweden) was used to check for enzyme homogeneity. Samples of papain released from the submicron particles in phosphate buffer $\mathrm{pH}$ 7.4, papain (reference standard), and a molecular weight reference marker (molecular weight 14-94 kDa) were dissolved in sample buffer containing sodium dodecyl sulfate and a reducing agent ( $\beta$-mercaptoethanol), loaded onto a vertical slab gel, and subjected to electrophoresis at $45 \mathrm{~mA}$. Protein bands were fixed and stained with Coomassie Brilliant Blue R-250 $(0.1 \% \mathrm{w} / \mathrm{v})$ in water:acetic acid:methanol (50:10:40).

\section{Fluorescence spectroscopy}

A fluorescence spectrometer (Cary Eclipse Fluorescence Spectrometer, Varian Australia Pty Ltd, Mulgrave, Australia) was used to detect changes in the tertiary structure of the papain-loaded submicron particles $\left(\mathrm{HS}_{4}, \mathrm{LS}_{4}\right.$, and $\left.\mathrm{SS}_{4}\right)$. The emission spectrum (300-500 nm) of each sample was collected at an excitation wavelength of $280 \mathrm{~nm}$. When excited at $280 \mathrm{~nm}$, the emission spectrum is a result of contributions 
from both tryptophan and tyrosine residues in the protein. ${ }^{22}$ Each protein spectrum was corrected by subtracting the spectrum of the appropriate blank solution (phosphate buffer $\mathrm{pH} 7.4)$.

\section{Fourier transform infrared spectroscopy}

Fourier transform infrared spectra of papain, HPMCP, Eudragit L100, Eudragit S100, and papain-loaded HPMCP $\left(\mathrm{HS}_{4}\right)$, Eudragit L100 $\left(\mathrm{LS}_{4}\right)$, and Eudragit S100 $\left(\mathrm{SS}_{4}\right)$ submicron particles were obtained using a Fourier transform infrared spectrometer (FTIR-8400S, Shimadzu, Kyoto, Japan) as $\mathrm{KBr}$ pellets in the range of $4000-400 \mathrm{~cm}^{-1}$.

\section{Powder x-ray diffraction}

The x-ray diffraction patterns for papain, HPMCP, Eudragit L100, Eudragit S100, and papain-loaded HPMCP $\left(\mathrm{HS}_{4}\right)$, Eudragit L100 ( $\left.\mathrm{LS}_{4}\right)$, and Eudragit S100 ( $\left.\mathrm{SS}_{4}\right)$ submicron particles were recorded using a x-ray diffractometer (Siemens, Model D5000, Munich, Germany) using $\mathrm{CuK} \alpha_{1}$ radiation of wavelength $1.5406 \AA$, generated at $45 \mathrm{kV}, 40 \mathrm{~mA}$, by measuring the angle of diffraction over the range of $3.0^{\circ}-45.0^{\circ} 2 \theta$.

\section{Differential scanning calorimetry}

The thermal characteristics of papain powder, HPMCP, Eudragit L100, Eudragit S100, and papain-loaded HPMCP $\left(\mathrm{HS}_{4}\right)$, Eudragit L100 $\left(\mathrm{LS}_{4}\right)$, and Eudragit S100 $\left(\mathrm{SS}_{4}\right)$ submicron particles were determined using a differential scanning calorimeter (DSC-60, Shimadzu). Samples were crimped in a standard aluminum pan and heated from $40^{\circ} \mathrm{C}$ to $250^{\circ} \mathrm{C}$ at a heating rate $10^{\circ} \mathrm{C}$ per minute under constant purging of nitrogen at $30 \mathrm{~mL} / \mathrm{min}$.

\section{Scanning electron microscopy}

Particle morphology was analyzed by scanning electron microscopy (LEO $435 \mathrm{VP}$ ) using an acceleration voltage of $2 \mathrm{kV}$. The surface microscopic structure of the submicron particles was also investigated. Particles were mounted on brass stubs using carbon paste. Scanning electron micrographs were taken using variable pressure scanning electron microscopy at the required magnification and room temperature.

\section{Stability testing}

Accurately weighed parent papain bulk or selected submicron particles $\left(\mathrm{HS}_{4}, \mathrm{LS}_{4}\right.$, and $\left.\mathrm{SS}_{4}\right)$ equivalent to $10 \mathrm{mg}$ of papain were filled into hard gelatin capsules (size 3). The capsules were packed in amber-colored glass bottles and subjected to stability testing according to the International Conference on Harmonization guidelines for zones III and IV.
The containers packed with prepared capsules of papain parent bulk or submicron particles were kept for accelerated $\left(40^{\circ} \mathrm{C} \pm 2{ }^{\circ} \mathrm{C} / 75 \% \pm 5 \%\right.$ relative humidity) and long-term $\left(30^{\circ} \mathrm{C} \pm 2{ }^{\circ} \mathrm{C} / 65 \% \pm 5 \%\right.$ relative humidity) stability for six months and 12 months, respectively. Samples kept under accelerated storage conditions were withdrawn at months 0 , $1.5,3$, and 6 , and papain activity was estimated. Similarly, samples stored at $30^{\circ} \mathrm{C} \pm 2{ }^{\circ} \mathrm{C} / 65 \% \pm 5 \%$ relative humidity were withdrawn at months $0,3,6,9$, and 12 , and analyzed for papain activity. Visual inspection of samples for discoloration of capsule content was also done after completion of the stability study.

\section{Results and discussion Formulation variables}

The effect of the formulation variables on yield, encapsulation efficiency, and size of HPMCP, Eudragit L100, and Eudragit S100 submicron particles prepared by this double emulsion solvent evaporation technique is shown in Table 2. With respect to the total amount of papain used for preparation, submicron particles made with Eudragit L100 and Eudragit S100 encapsulated a larger amount of papain compared with HPMCP (Table 2). This could be due to a difference in the molecular weight of the polymers. Low molecular weight polymers incorporate a smaller amount of protein than those of higher molecular weight. ${ }^{23,24}$

The type of polymer and volume of the internal aqueous phase affected the encapsulation efficiency of the papainloaded submicron particles. It was observed that as the volume of internal aqueous phase decreased from $0.4 \mathrm{~mL}$ to $0.05 \mathrm{~mL}$, the encapsulation efficiency increased and particle size decreased for all the polymeric particles, although the extent varied slightly. The mean diameter of the submicron particles varied from $665.6 \pm 34 \mathrm{~nm}$ to $2785.6 \pm 45 \mathrm{~nm}$ with varying internal aqueous phase volume from $50 \mu \mathrm{L}$ to $400 \mu \mathrm{L}$ for all three polymers used in the study. Use of a $50 \mu \mathrm{L}$ internal aqueous phase provided the highest papain-loading efficiency and the smallest particle size for HPMCP $(75.58 \% \pm 4.03 \%$ and $665.6 \pm 34$ nm, respectively), Eudragit L100 (81.17\% $\pm 2.88 \%$ and $692.4 \pm 62 \mathrm{~nm})$, and Eudragit S100 (82.35\% $\pm 3.10 \%$ and $676.4 \pm 66 \mathrm{~nm}$ ) submicron particles (Table 2).

It has been reported that the droplet size of a primary emulsion may increase with an increase in the volume of the internal phase which, in turn, may be responsible for the increase in size of particles. ${ }^{25,26}$ Accordingly, during formation of a primary emulsion, sonication of a small volume leads to smaller droplet formation, which could account for a smaller particle size. A higher rate of leaching, poor 
Table 2 Effect of formulation variables on yield, encapsulation efficiency and particle size of HPMCP, Eudragit L I00 and Eudragit S I00 SPs prepared by double emulsion solvent evaporation technique

\begin{tabular}{|c|c|c|c|c|c|c|}
\hline $\begin{array}{l}\text { Formulation } \\
\text { code }\end{array}$ & $\begin{array}{l}\text { Yield (\%) } \\
\text { (mean } \pm \text { SE) }\end{array}$ & $\begin{array}{l}\text { Theoretical } \\
\text { loading (\%) }\end{array}$ & $\begin{array}{l}\text { Actual } \\
\text { loading (\%) }\end{array}$ & $\begin{array}{l}\text { Encapsulation efficiency } \\
(\text { mean } \pm \text { SE) (\%) }\end{array}$ & $\begin{array}{l}\text { Particle size } \\
(\text { mean } \pm \text { SE) } \mathrm{nm}\end{array}$ & $\begin{array}{l}\text { Poly dispersity } \\
\text { index }\end{array}$ \\
\hline$\overline{\mathrm{HS}}$ & $49.66 \pm 2.60$ & 21.95 & $2.71 \pm 0.39$ & $12.34 \pm 1.77$ & $2725.1 \pm 32$ & 0.678 \\
\hline $\mathrm{HS}_{2}$ & $51.88 \pm 1.53$ & 12.34 & $2.80 \pm 0.40$ & $22.69 \pm 3.25$ & $1281.8 \pm 28$ & 0.519 \\
\hline $\mathrm{HS}_{3}$ & $52.55 \pm 3.27$ & 6.58 & $2.74 \pm 0.30$ & $41.64 \pm 4.62$ & $915.6 \pm 48$ & 0.568 \\
\hline $\mathrm{HS}_{4}$ & $54.05 \pm 3.17$ & 3.40 & $2.57 \pm 0.14$ & $75.58 \pm 4.03$ & $665.6 \pm 34$ & 0.221 \\
\hline $\mathrm{HS}_{5}$ & $54.00 \pm 3.21$ & 3.40 & $2.4 I \pm 0.10$ & $70.88 \pm 3.05$ & $708.3 \pm 31$ & 0.365 \\
\hline $\mathrm{HS}_{6}$ & $56.55 \pm 1.94$ & 3.40 & $2.31 \pm 0.12$ & $67.94 \pm 3.57$ & $787.1 \pm 35$ & 0.269 \\
\hline $\mathrm{LS}_{1}$ & $50.13 \pm 4.11$ & 21.95 & $3.15 \pm 0.23$ & $14.35 \pm 1.06$ & $2476.7 \pm 36$ & 0.667 \\
\hline $\mathrm{LS}_{2}$ & $54.5 \mathrm{I} \pm 4.87$ & 12.34 & $3.17 \pm 0.17$ & $25.68 \pm 1.36$ & $172 \mid .4 \pm 56$ & 0.723 \\
\hline $\mathrm{LS}_{3}$ & $50.46 \pm 3.67$ & 6.58 & $2.99 \pm 0.26$ & $45.44 \pm 3.99$ & $1075.3 \pm 45$ & 0.476 \\
\hline $\mathrm{LS}_{4}$ & $56.56 \pm 4.61$ & 3.40 & $2.76 \pm 0.10$ & $81.17 \pm 2.88$ & $692.4 \pm 62$ & 0.225 \\
\hline $\mathrm{LS}_{5}$ & $52.52 \pm 2.37$ & 3.40 & $2.69 \pm 0.14$ & $79.11 \pm 4.04$ & $710.3 \pm 24$ & 0.373 \\
\hline $\mathrm{LS}_{6}$ & $57.22 \pm 3.81$ & 3.40 & $2.57 \pm 0.15$ & $75.58 \pm 4.45$ & $801.2 \pm 73$ & 0.559 \\
\hline $\mathrm{SS}_{\mathrm{I}}$ & $51.23 \pm 4.27$ & 21.95 & $3.14 \pm 0.27$ & $14.30 \pm 1.22$ & $2785.6 \pm 45$ & 0.618 \\
\hline $\mathrm{SS}_{2}$ & $58.16 \pm 4.16$ & 12.34 & $3.14 \pm 26$ & $25.44 \pm 2.15$ & $1705.2 \pm 24$ & 0.755 \\
\hline $\mathrm{SS}_{3}$ & $55.08 \pm 3.67$ & 6.58 & $2.93 \pm 0.20$ & $44.52 \pm 3.02$ & $1097.4 \pm 58$ & 0.305 \\
\hline $\mathrm{SS}_{4}$ & $53.16 \pm 4.16$ & 3.40 & $2.80 \pm 0.11$ & $82.35 \pm 3.10$ & $676.4 \pm 66$ & 0.282 \\
\hline $\mathrm{SS}_{5}$ & $54.12 \pm 2.57$ & 3.40 & $2.70 \pm 0.12$ & $79.41 \pm 3.57$ & $747.2 \pm 23$ & 0.670 \\
\hline $\mathrm{SS}_{6}$ & $53.31 \pm 2.34$ & 3.40 & $2.58 \pm 0.13$ & $75.88 \pm 3.68$ & $801.8 \pm 20$ & 0.762 \\
\hline
\end{tabular}

physical stability of the primary emulsion, and an increase in the number of pores on the surface of the nanospheres may be responsible for the decrease in encapsulation efficiency associated with the increase in volume of the internal phase of the primary emulsion. ${ }^{27,28}$ Thus, a smaller volume of the internal aqueous phase is desirable for higher encapsulation of papain and particles of smaller size. This improved encapsulation efficiency may be simply due to a relatively greater proportion of polymer with respect to the amount of enzyme. The amount of polymer in the organic phase is constant but the volume of the internal aqueous phase is variable. Therefore, there is a relative increase in the polymer load with a decrease in the volume of the internal aqueous phase. The increase in polymer load leads to a shorter time for the composition of the polymer solution to reach the viscous (gelation) boundary, resulting in rapid formation of a film-like membrane on the periphery of the droplets. If the film-like polymeric membrane is quickly solidified, the microparticle structure is more fixed and thus solvent and nonsolvent counter diffusion is delayed. As a consequence, less water may be able to diffuse into the dispersed phase and less drug (or enzyme) will be carried by the solvent into the aqueous phase. ${ }^{29}$ A polydispersity index (Table 2) of submicron particles in the range of $0.15-0.3$ indicates reasonable size homogeneity, while a polydispersity index $>0.3$ indicates heterogeneity. ${ }^{30}$ The optimized ratio of the internal aqueous phase to organic phase was 1:100, ie, $50 \mu \mathrm{L}$ of internal aqueous phase and $5 \mathrm{~mL}$ of organic phase.
The effect of a change in volume of the external aqueous phase on encapsulation efficiency of the particles was also studied. As the volume of external aqueous phase was increased from $16 \mathrm{~mL}$ to $50 \mathrm{~mL}$, the encapsulation efficiency decreased and particle size increased (Table 2). Thus, for maximum encapsulation, the optimized ratio of the internal aqueous $\left(\mathrm{W}_{1}\right)$ :organic:external aqueous $\left(\mathrm{W}_{2}\right)$ phases was 1:100:320 (ie, $50 \mu \mathrm{L}$ internal aqueous phase to $5 \mathrm{~mL}$ organic phase to $16 \mathrm{~mL}$ of external aqueous phase).

Jain et $\mathrm{a}^{31,32}$ encapsulated porcine insulin in Eudragit L100 and Eudragit S100 microspheres using a w/o/w emulsion solvent evaporation and observed actual drug loading of $0.45 \%$ and $0.43 \%$ and an encapsulation efficiency of $84.5 \%$ and $81.8 \%$, respectively. In the present experiment, the actual drug loading of papain in the Eudragit L100 and Eudragit S100 submicron particles was $2.76 \%$ and $2.80 \%$, respectively, and the corresponding encapsulation efficiency was $81.17 \%$ and $82.35 \%$. The higher drug loading observed in the present study appears to be due to use of a higher concentration of papain in the internal aqueous phase compared with insulin $(141.06 \mathrm{mg} / \mathrm{mL}$ of papain against $32 \mathrm{mg} / \mathrm{mL}$ of insulin). The yield of submicron particles obtained from the different batches of polymers varied from $49.66 \%$ to $58.16 \%$, irrespective of enzyme loading. The low yield of submicron particles could be attributable to losses occurring during various steps of processing, such as adherence of the polymeric solution to the glass container and loss of submicron particles during the washing step. Loss due to 
adherence could be minimized by using apparatus made of plastic or polyethylene.

During preparation of the submicron particles, the papain activity decreased from 887.92 CDU to 672.08 CDU, 628.75 CDU, and 644.58 CDU for HPMCP, Eudragit L100, and Eudragit S100 particles, respectively. A loss of enzyme activity of about $25 \%-30 \%$ was observed under the conditions of the experiment for optimized formulations of the three different polymers. This might be due to the denaturing effect of the mixed organic solvent system, mechanical stress exerted by the probe during sonication, and exposure to vacuum during lyophilization.

\section{Enteric nature of submicron particles}

Studies of the optimized formulations revealed that release of papain from the papain-loaded submicron particles was mainly influenced by the nature of the polymer, as well as the $\mathrm{pH}$ of the surrounding media. Complete enteric coating could not be achieved because $8.39 \%, 6.01 \%$, and $7.75 \%$ of papain was released from HPMCP $\left(\mathrm{HS}_{4}\right)$, Eudragit L100 ( $\left.\mathrm{LS}_{4}\right)$, and Eudragit S100 $\left(\mathrm{SS}_{4}\right)$ particles, respectively, in $0.1 \mathrm{~N}$ $\mathrm{HCl}(\mathrm{pH} \mathrm{1.2)}$ in two hours. The release of enzyme from the submicron particles in acidic medium could be due to insufficient coating or film defects created during lyophilization. Since the polymers are insoluble in the release media of $\mathrm{pH}$ 1.2 , the particles were only slightly swollen and remained intact in this case. Studies in which papain was immobilized in ionotropically crosslinked kappa-carrageenan and sodium alginate gel beads reported release of $90 \%$ of papain from the formulation within 50 minutes in simulated gastric fluid. ${ }^{33,34}$ As a result, papain would remain almost inactive as well as lose its structural integrity at low $\mathrm{pH}$ in the stomach $(\mathrm{pH} 1.2)$. Hence, an adequate amount of papain would not reach the target site (intestine) for digestion of proteins. Thus, use of an enteric polymer matrix system for oral delivery of papain would be satisfactory (because the enzyme is not released from the optimized formulation in a significant amount in the stomach) for maintaining the structural integrity of the enzyme during transit through the stomach.

The submicron particles had a negative charge contributed by the carboxylic groups of phthalic acid ( $\mathrm{pKa}$ about 4.47 ) and methacrylic acid (pKa about 4.23) residues in the enteric polymer backbone. The zeta potentials of the aqueous dispersion of formulations $\mathrm{HS}_{4}, \mathrm{LS}_{4}$, and $\mathrm{SS}_{4}$ were found to be $-25.14,-27.33$, and $-28.27 \mathrm{mV}$, respectively. It was observed that the zeta potential of $\mathrm{HS}_{4}, \mathrm{LS}_{4}$, and $\mathrm{SS}_{4}$ particles was changed in $0.1 \mathrm{~N} \mathrm{HCl}$ to $0.3051,0.1154$, and $0.2682 \mathrm{mV}$, respectively. Optical microscopy showed aggregation of the particles in $0.1 \mathrm{~N} \mathrm{HCl}$ ( $\mathrm{pH} 1.2$, Figure 1). We know that the carboxylic groups of anionic particles become protonated if the $\mathrm{pH}$ is below the $\mathrm{pK}_{\mathrm{a}}$ of the carboxylic acid, leading to a decrease in the surface charge of the particles. Reduction in surface charge diminishes electrostatic repulsion and increases the Van der Waals forces between the particles, facilitating aggregation. ${ }^{35}$ Thus, it appears quite natural that the submicron particles would aggregate in $0.1 \mathrm{~N} \mathrm{HCl}$ which has a $\mathrm{pH} 1.2$ below the $\mathrm{pK}_{\mathrm{a}}$ of phthalic acid ( $\mathrm{pKa}$ about 4.47) and methacrylic acid (pKa about 4.23). ${ }^{36}$ Addition of $0.5 \%$ soybean oil did not have any appreciable effect on the zeta potential in $0.1 \mathrm{~N} \mathrm{HCl}$ or on aggregation. It has been reported that the stomach retains food particles until these are fragmented into particles smaller than $0.5 \mathrm{~mm}$ in diameter. ${ }^{37}$ Since the size of aggregated submicron particles was less than $500 \mu \mathrm{m}$, there should not be any significant delay in gastric emptying of the particles. Subsequent to gastric emptying, the particles would enter the duodenum where the $\mathrm{pH}$ is $>5.0$. Accordingly, as the $\mathrm{pH}$ of the dispersion of submicron particles in $0.1 \mathrm{~N} \mathrm{HCl}$ was raised to 5.3, deaggregation of particles was observed due to $\mathrm{pH}$-induced deprotonation of carboxylic groups and restoration of negative charge. The result suggests that the particles, on being emptied by the stomach into the duodenum, which has a $\mathrm{pH}>5.0$, would undergo deaggregation, resulting in an increase in the effective surface area of the particles.

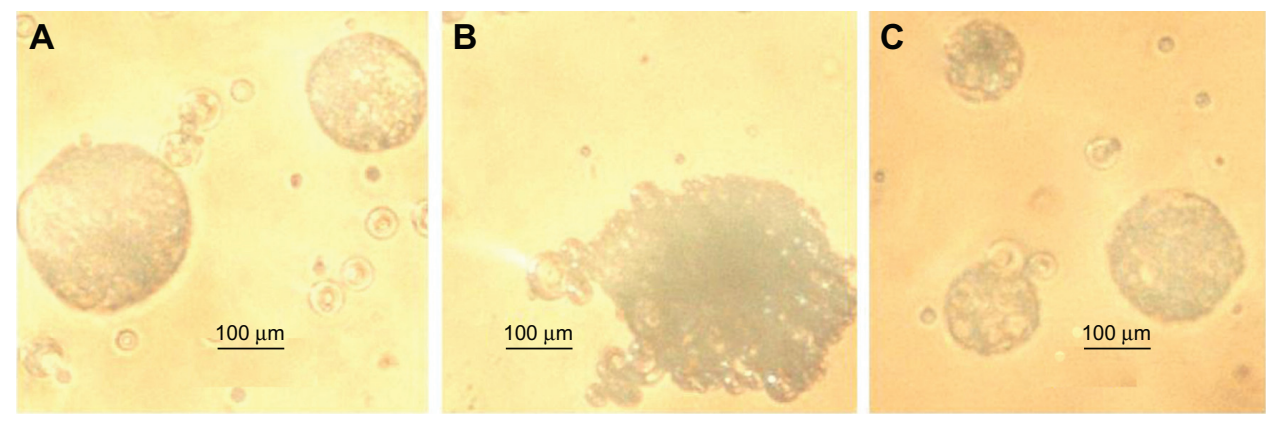

Figure I Effect of pH I.2 on the aggregation of optimized papain loaded enteric SPs of HPMCP (A), Eudragit L I00 (B) and Eudragit S I00 (C). 


\section{In vitro release profile}

In vitro drug release from all the optimized batches of submicron particles showed $6.01 \%-8.39 \%$ of drug release in $0.1 \mathrm{~N} \mathrm{HCl}(\mathrm{pH} 1.2)$ in two hours. Next, the drug release was studied at $\mathrm{pH}$ 6.0, 6.8, and 7.4 for the HPMCP, Eudragit L100, and Eudragit S100 particles, respectively. HPMCP particles showed almost complete drug release in half an hour at all pHs studied, whereas Eudragit L100 particles showed $20.71 \%$ and $88.82 \%$ drug release at $\mathrm{pH} 6.0$ and 6.8, respectively, during the same time interval (Figure 2). Eudragit S100 particles showed only $13.01 \%-15.23 \%$ drug release at pH 6.0 and 6.8 compared with $53.00 \%$ release at pH 7.4 in 30 minutes. However, complete release of drug from $\mathrm{LS}_{4}$ and $\mathrm{SS}_{4}$ particles at $\mathrm{pH} 6.8$ and 7.4 was obtained in 40 minutes and 70 minutes, respectively. The drug release from these particles is consistent with the $\mathrm{pH}$-dependent solubility of the polymers, because HPMCP dissolves at a $\mathrm{pH}$ of around 5.0-5.5, while Eudragit L100 and Eudragit S100 dissolve at $\mathrm{pH}>6.0$ and $\mathrm{pH}>7.0$, respectively. ${ }^{38}$

\section{Release kinetics}

The enzyme release data show a good fit to the KorsmeyerPeppas equation, which can be confirmed by comparing the values for the regression coefficient of the zero order
$\left(\mathrm{R}_{0}{ }^{2}=0.944,0.967\right.$, and 0.969 for $\mathrm{HS}_{4}, \mathrm{LS}_{4}$, and $\left.\mathrm{SS}_{4}\right)$, first order $\left(\mathrm{R}_{1}^{2}=0.893,0.887\right.$, and 0.946), Higuchi matrix $\left(\mathrm{R}^{2}=0.990,0.993\right.$, and 0.971) and Korsmeyer-Peppas $\left(\mathrm{R}_{\mathrm{k}}^{2}=0.993,0.995\right.$, and 0.979$)$ equations. The value of $\mathrm{n}$ $(0.43<\mathrm{n}<0.85)$, ie, the diffusion exponent of the KorsmeyerPeppas equation, indicates that the release of papain from $\mathrm{HS}_{4}, \mathrm{LS}_{4}$, and $\mathrm{SS}_{4}$ particles is anomalous, ie, contributed to by a combination of dissolution and diffusion. The release mechanism of dissolution and diffusion from anionic polymers (HPMCP, Eudragit L100, and Eudragit S100) is pH-dependent. ${ }^{39}$

\section{Digestion of paneer and milk protein}

Milk and paneer are the most common sources of dietary protein consumed on the Indian subcontinent. Thus, assuming the maximum gastrointestinal transit time through the absorptive areas of the gastrointestinal tract to be 12 hours ${ }^{40}$ the ability of the $\mathrm{HS}_{4}, \mathrm{LS}_{4}$ and $\mathrm{SS}_{4}$ formulations to digest paneer and milk protein was evaluated in progressive $\mathrm{pH}$ media simulating gastrointestinal $\mathrm{pH}$ conditions. The substrate (milk or paneer) was successively exposed to the submicron particles at $\mathrm{pH}$ 1.2 for two hours, $\mathrm{pH} 6.0$ for two hours, $\mathrm{pH} 6.8$ for two hours, and $\mathrm{pH} 7.4$ for two hours. It was observed that $8.61 \pm 4.56 \mathrm{mg}$ and $0.23 \pm 4.23 \mathrm{mg}$ of tyrosine was formed from paneer with

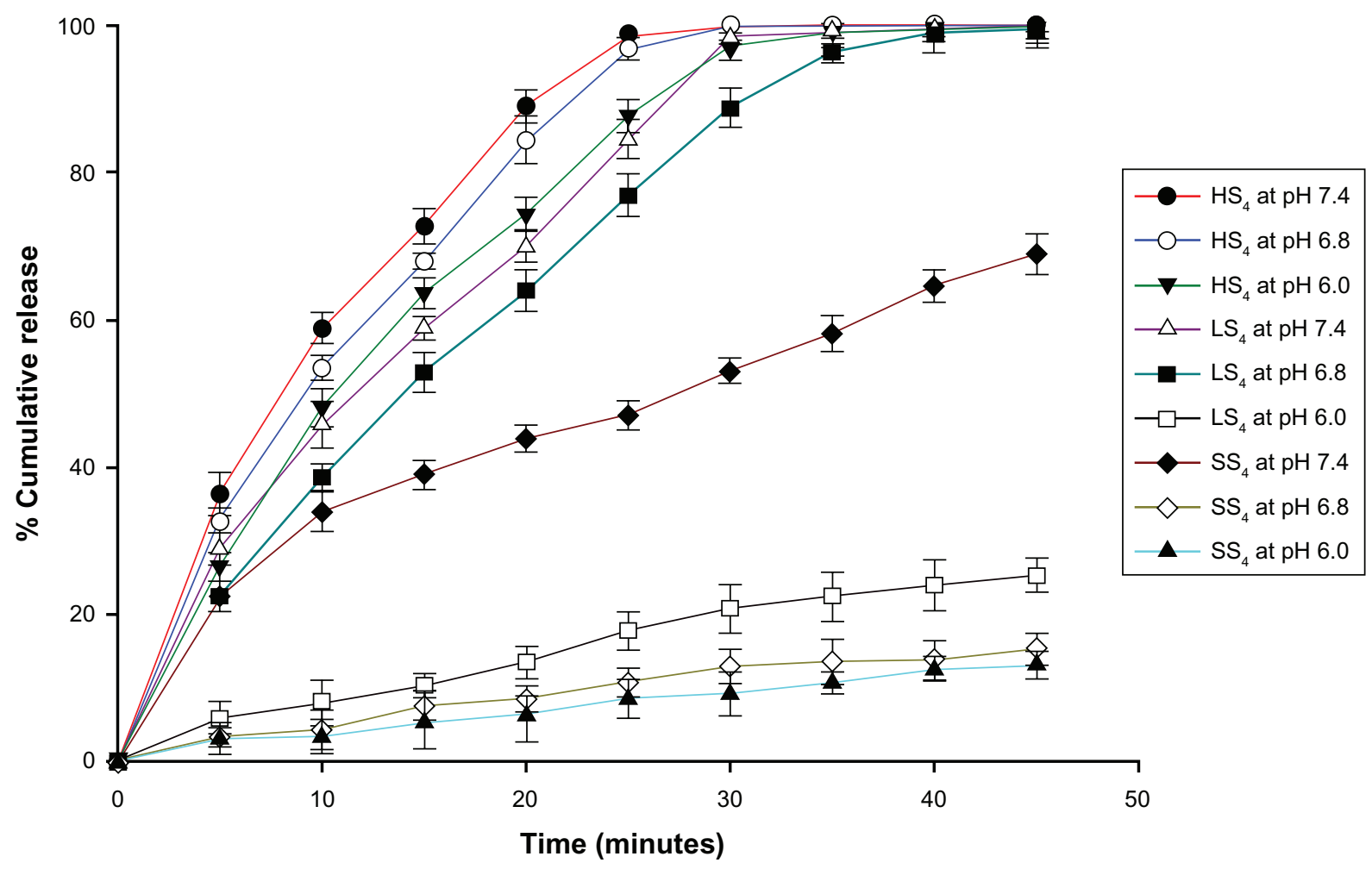

Figure 2 Effect of pH on the release of enzyme from the optimized formulation of papain loaded SPs of HPMCP $\left(\mathrm{HS}_{4}\right)$, Eudragit $\mathrm{L} 100\left(\mathrm{LS}_{4}\right)$ and Eudragit S I00 $\left(\mathrm{SS}_{4}\right)$ at pH $6,6.8$ and 7.4 respectively. 
$\mathrm{HS}_{4}$ and $\mathrm{LS}_{4}$ at $\mathrm{pH} 6.0$ after two hours, whereas $8.72 \pm 3.92 \mathrm{mg}$ and $0.42 \pm 3.42 \mathrm{mg}$ of tyrosine was formed from milk. Subsequently, as the $\mathrm{pH}$ was raised to 6.8 , the total amount of tyrosine formed from paneer was $8.64 \pm 3.68 \mathrm{mg}, 8.88 \pm 4.16 \mathrm{mg}$, and $0.12 \pm 3.17 \mathrm{mg}$ with $\mathrm{HS}_{4}, \mathrm{LS}_{4}$, and $\mathrm{SS}_{4}$ in two hours while $8.69 \pm 4.52 \mathrm{mg}, 8.77 \pm 4.66 \mathrm{mg}$, and $0.17 \pm 4.53 \mathrm{mg}$ of tyrosine was formed from milk. With a further increase in $\mathrm{pH}$ from 6.8 to 7.4 , the total amount of tyrosine formed from paneer was $8.64 \pm 3.22 \mathrm{mg}, 8.91 \pm 3.94 \mathrm{mg}$, and $8.03 \pm 3.45 \mathrm{mg}$ with $\mathrm{HS}_{4}, \mathrm{LS}_{4}$, and $\mathrm{SS}_{4}$, respectively, after two hours, whereas the corresponding tyrosine formed from milk was $8.71 \pm 3.98 \mathrm{mg}$, $8.98 \pm 3.64 \mathrm{mg}$, and $8.24 \pm 4.28 \mathrm{mg}$. Thus, HPMCP and Eudragit L100 particles would have good digestive power for protein/peptides at $\mathrm{pH} 6.0$ and 6.8, respectively, during a short gastro-small intestinal transit time of 4-6 hours, ${ }^{41}$ whereas Eudragit S100 particles would take longer to digest. This indicates that in an in vivo situation, as the submicron particles pass through the stomach to the intestine, uniform mixing of the submicron particles with chyme would facilitate digestion of proteins.

\section{SDS-PAGE}

SDS-PAGE analysis of both papain and papain released from the $\mathrm{HS}_{4}, \mathrm{LS}_{4}$, and $\mathrm{SS}_{4}$ particles demonstrated that neither protein fragmentation nor covalent dimerization occurred during the encapsulation process (Figure 3). There were no additional bands to indicate the presence of aggregates (molecular weight $>23 \mathrm{kDa}$ ) or other fragments produced by hydrolysis

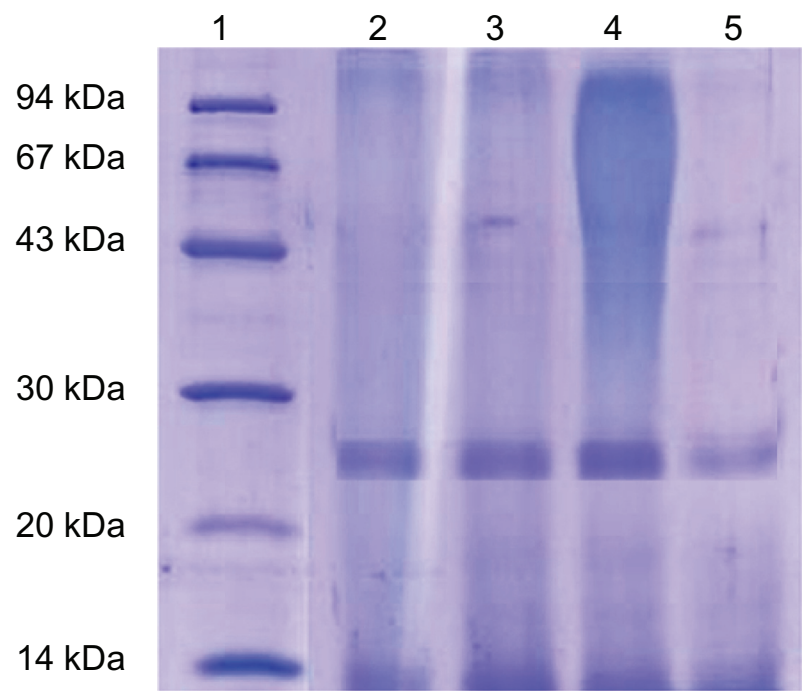

Figure 3 SDS-PEGE analysis of papain samples. Lane I: molecular weight markers (14-94kDa); lane 2: papain (reference standard); lane 3, 4 and 5: papain released from optimized formulations of papain loaded HPMCP, Eudragit L 100 and Eudragit S 100 SPs respectively.

of enzyme proteins (molecular weight $<23 \mathrm{kDa}$ ). Hence, the data suggest that the structural integrity (ie, primary structure) of papain was not significantly affected during the entrapment procedure (and in potentially harsh conditions, such as contact with organic solvents and mechanical agitation).

\section{Fluorescence spectroscopy}

The fluorescence spectra of papain and papain released from the $\mathrm{HS}_{4}, \mathrm{LS}_{4}$, and $\mathrm{SS}_{4}$ particles are compared in Figure 4. The $\lambda_{\text {max }}$ of the nonentrapped papain spectrum was $332 \mathrm{~nm}$.

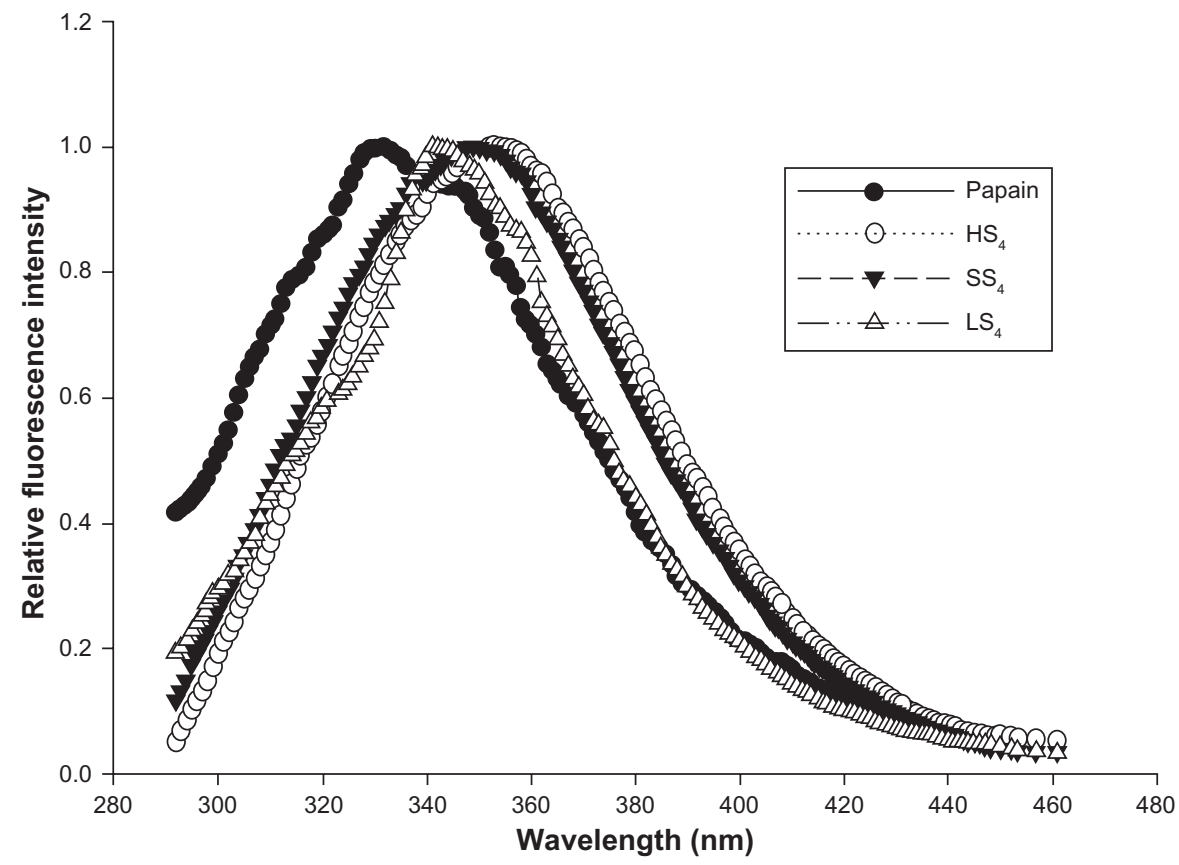

Figure 4 Intrinsic fluorescence spectra of papain (reference standard) and papain released from optimized formulations of papain loaded HPMCP, Eudragit L I00 and Eudragit S 100 SPs respectively. 
Papain released from the $\mathrm{HS}_{4}, \mathrm{LS}_{4}$, and $\mathrm{SS}_{4}$ particles showed a slight shift in $\lambda_{\max }$ to longer wavelengths. However, $\lambda_{\max }$ was within the acceptable range of $300-350 \mathrm{~nm}$, corresponding to the intense emission of tryptophan. ${ }^{42}$ Thus, the $\mathrm{HS}_{4}, \mathrm{LS}_{4}$, and $\mathrm{SS}_{4}$ particles maintained the tertiary structure of papain under encapsulated conditions.

\section{Fourier transform infrared spectroscopy}

The Fourier transform infrared spectra of papain, Eudragit L100, Eudragit S100, HPMCP, papain-loaded Eudragit L100 $\left(\mathrm{LS}_{4}\right)$, Eudragit S100 $\left(\mathrm{SS}_{4}\right)$, and HPMCP $\left(\mathrm{HS}_{4}\right)$ particles are shown in Figure 5. The Eudragit L100 and Eudragit S100 polymers contain both carboxylic acid and ester groups.

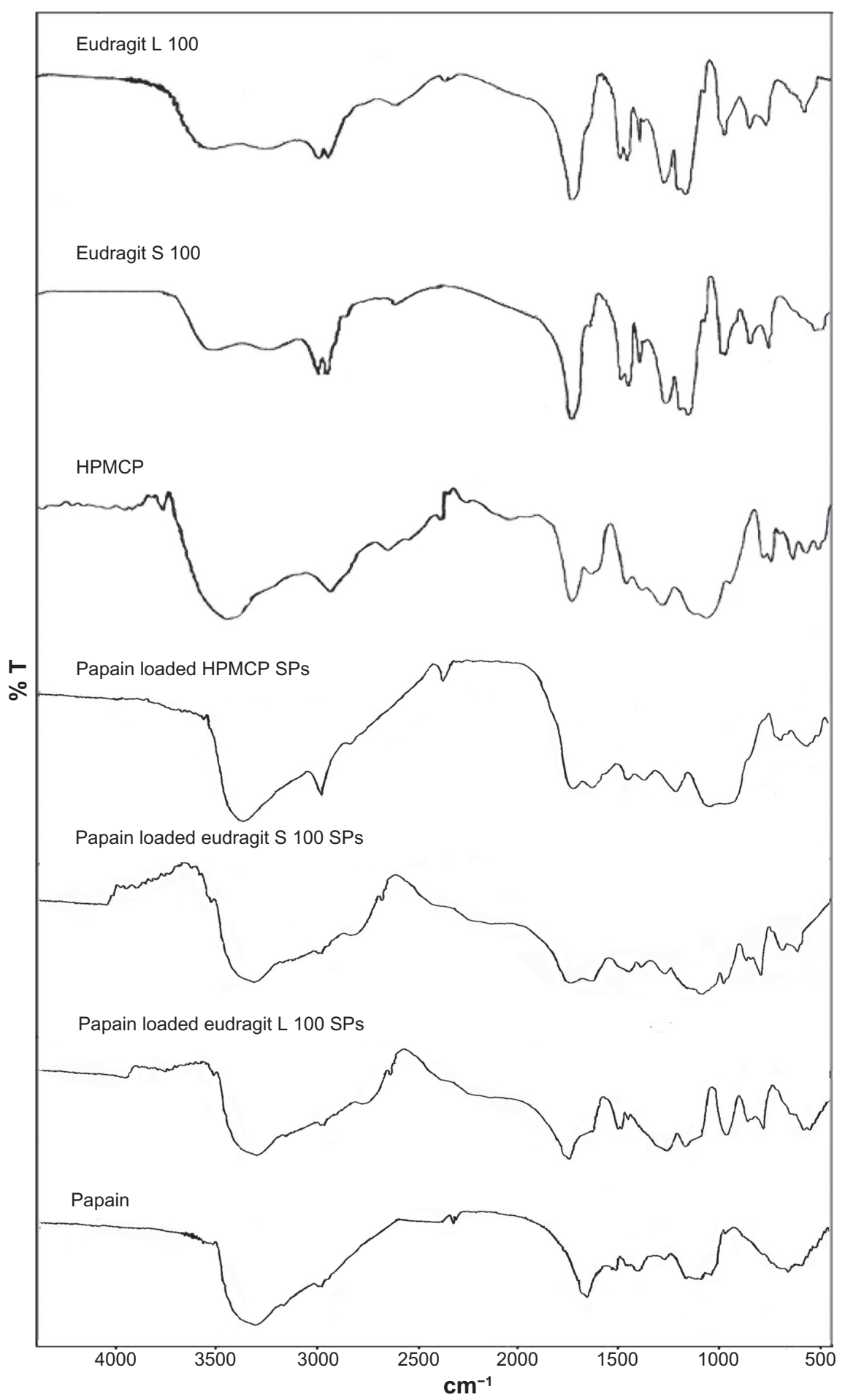

Figure 5 The FTIR spectra Eudragit L 100, Eudragit S 100, HPMCP, papain powder and optimized formulation of papain loaded HPMCP, Eudragit L I00 and Eudragit S I00 SPs. 
The spectra of Eudragit L100 and Eudragit S100 show the carbonyl vibrations of the ester group at around $1728 \mathrm{~cm}^{-1}$. The HPMCP polymer shows a broad band in the region of $3500-3250 \mathrm{~cm}^{-1}$, having a peak at $3438 \mathrm{~cm}^{-1}$ due to a polyhydroxyl $(-\mathrm{OH})_{\mathrm{n}}$ group and an ester $\mathrm{C}=\mathrm{O}$ stretching at $1735.3 \mathrm{~cm}^{-1}$. Papain also showed one predominant band at $3450-3225 \mathrm{~cm}^{-1}$, having a peak at $3300 \mathrm{~cm}^{-1}$ due to the $\mathrm{N}-\mathrm{H}$ stretch of a secondary $\mathrm{N}$-substituted amide, p-substituted aromatic out of plane $\mathrm{C}-\mathrm{H}$ deformation of an aromatic residue of tryptophan or tyrosine at $868 \mathrm{~cm}^{-1}$ and $850 \mathrm{~cm}^{-1}$, with $\mathrm{C}=\mathrm{O}$ stretch of a carboxylate anion and an amide group at
$1654.2 \mathrm{~cm}^{-1}$, and strong peaks between $1150-1050 \mathrm{~cm}^{-1}$ and $705-570 \mathrm{~cm}^{-1}$ due to $\mathrm{C}-\mathrm{S}$ stretch of sulfides and disulfides. The spectra of the papain-loaded enteric submicron polymer particles showed peaks at $3386.2 \mathrm{~cm}^{-1}$ for the substituted secondary amide, $875 \mathrm{~cm}^{-1}$ due to the substituted aromatic ring, and $1145 \mathrm{~cm}^{-1}$ and $600 \mathrm{~cm}^{-1}$ due to $\mathrm{C}-\mathrm{S}$ stretch of sulfides and disulfides, suggesting entrapment of the enzyme.

\section{Powder x-ray diffraction}

Figure 6 shows the powder diffraction patterns for papain, HPMCP, Eudragit L100, Eudragit S100, and optimized

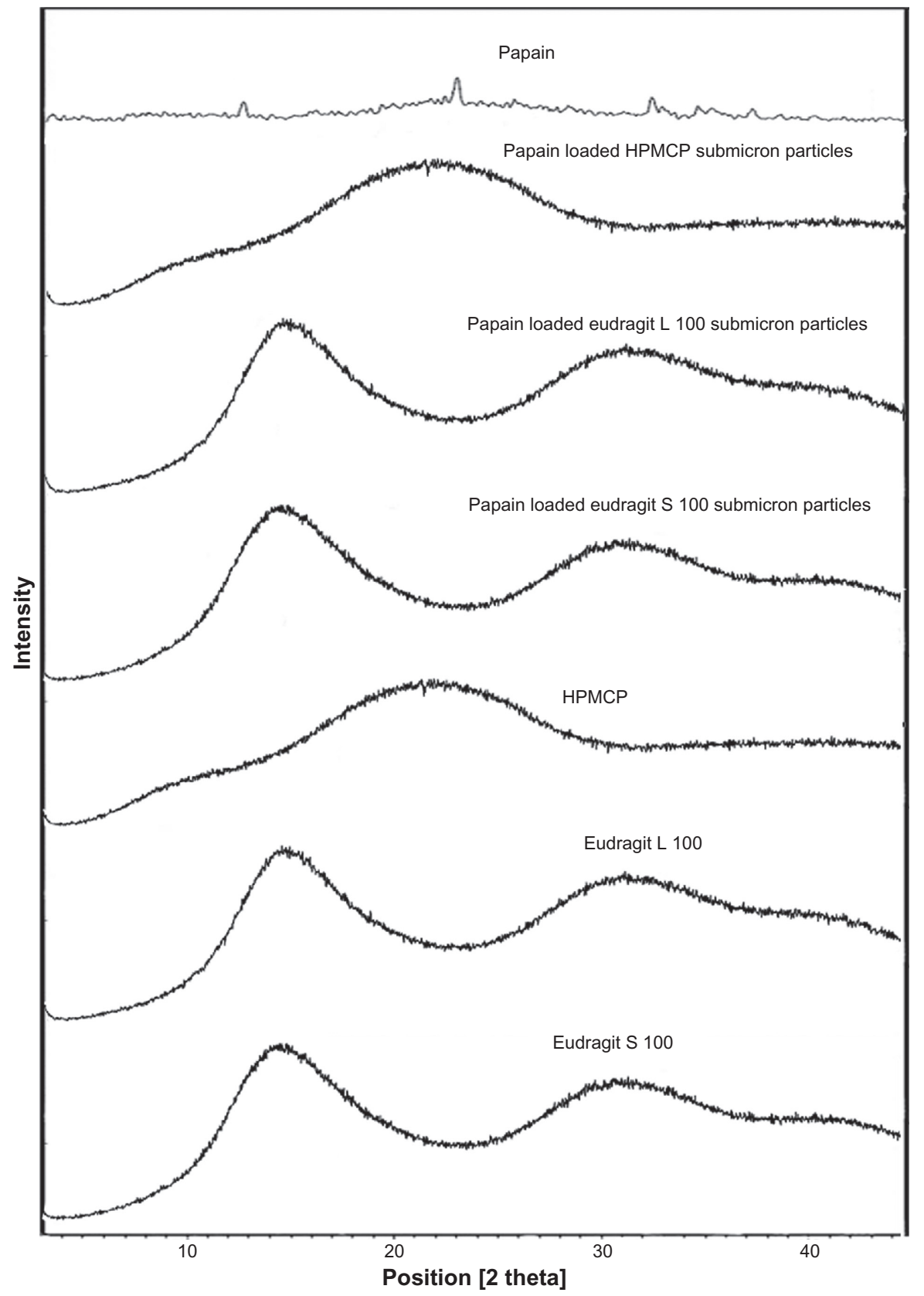

Figure 6 XRD pattern of Eudragit S 100, Eudragit L I00, HPMCP, papain powder and optimized formulation of papain loaded HPMCP, Eudragit L I00 and Eudragit S I00 SPs. 
papain-loaded submicron particles of HPMCP, Eudragit L100, and Eudragit S100. The diffractograms of papain and the polymers indicated an amorphous structure. The diffractograms for the submicron particles also indicated an amorphous structure, and those for the submicron particles appeared identical to the HPMCP, Eudragit L100, and Eudragit S100 polymers.

\section{Differential scanning calorimetry}

The differential scanning calorimetry thermograms of papain, HPMCP, Eudragit L100, Eudragit S100 and optimized papain-loaded submicron particles of $\mathrm{HPMCP}\left(\mathrm{HS}_{4}\right)$, Eudragit L100 $\left(\mathrm{LS}_{4}\right)$, and Eudragit S100 $\left(\mathrm{SS}_{4}\right)$ are shown in Figure 7. Papain showed two endothermic peaks at $74.49^{\circ} \mathrm{C}$ and $174.47^{\circ} \mathrm{C}$. Eudragit L100 and Eudragit S100 showed

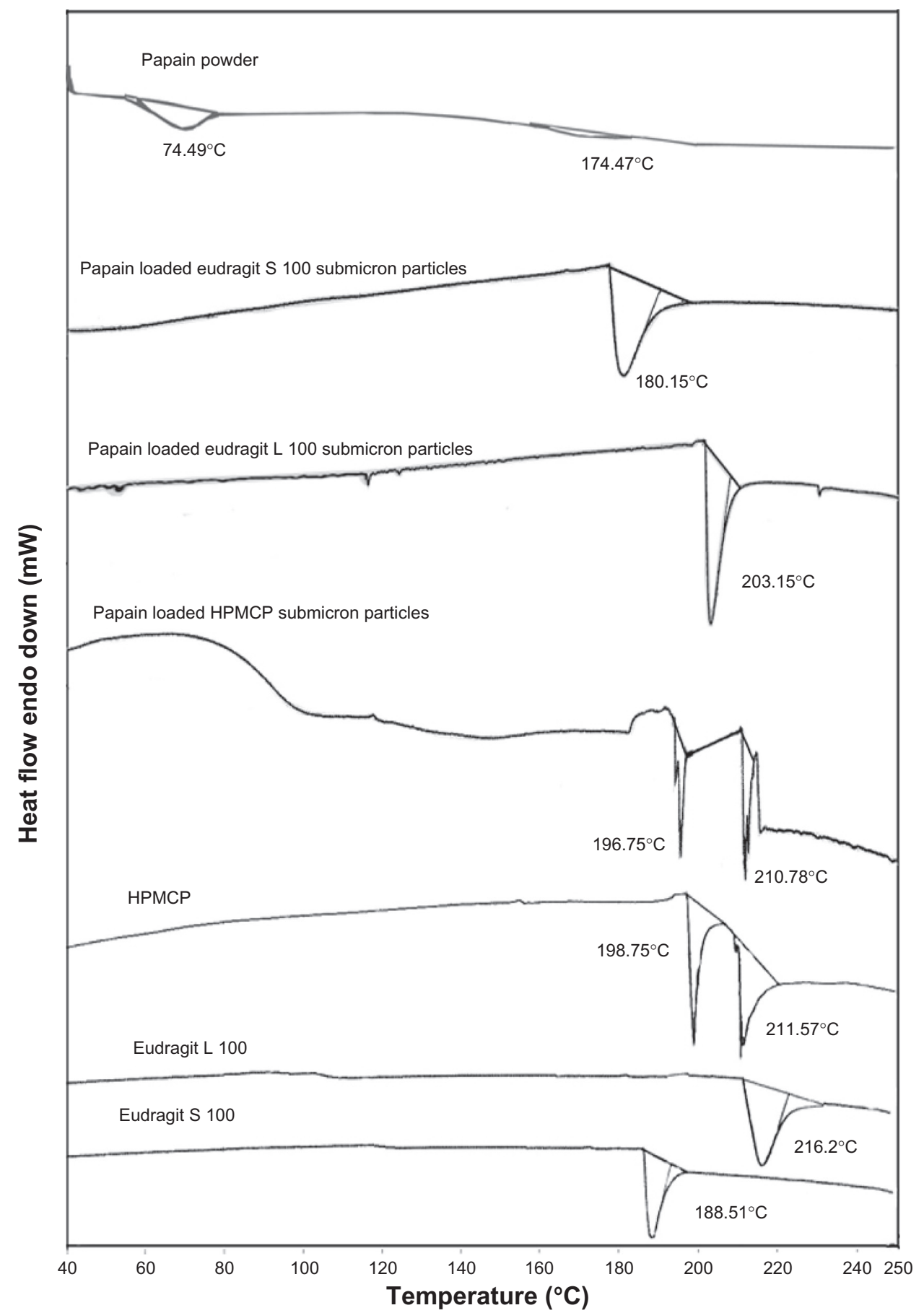

Figure 7 The DSC thermograms of Eudragit S 100, Eudragit L 100, HPMCP, papain powder and optimized formulations of papain loaded Eudragit S 100 , Eudragit L 100 and HPMCP SPs. 

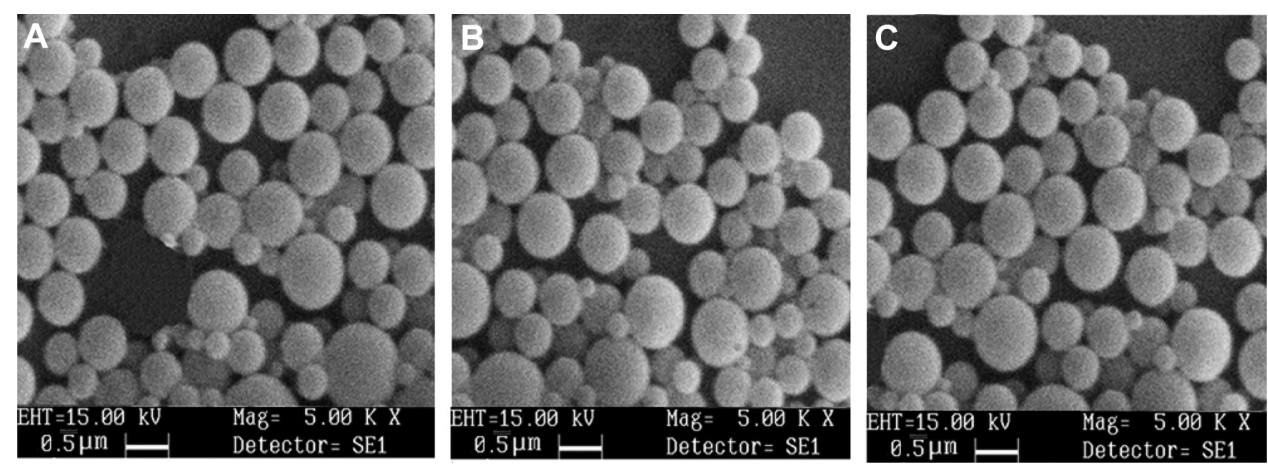

Figure 8 SEM micrographs of optimised formulations of papain loaded HPMCP (A), Eudragit L 100 (B) and Eudragit S 100 SPs (C).

a broad endotherm with a peak at $216.2^{\circ} \mathrm{C}$ and $188.51^{\circ} \mathrm{C}$, respectively, while HPMCP exhibited two broad endotherms at $198.75^{\circ} \mathrm{C}$ and $211.57^{\circ} \mathrm{C}$, which are typical of amorphous material. Differential scanning calorimetry thermograms of papain-loaded submicron polymeric particles were similar to the thermograms of the respective polymers, but the polymeric peaks were shifted to lower temperatures because papain was present as an impurity $(2.57 \%-2.80 \%)$. However, the thermograms did not show any melting peak analogous to papain. Maghsoodi ${ }^{43}$ prepared naproxen-loaded microparticles with Eudragit L100. Differential scanning calorimetry thermograms of these microparticles revealed that the melting peak of naproxen disappeared gradually with an increasing ratio of Eudragit L100 to drug in the formulation. When the ratio of Eudragit L100 to drug was 4:1, no melting peak of drug was observed. The results suggest that naproxen had been highly dispersed in the microparticles at a $4: 1$ polymer/ drug ratio, similar to an amorphous state. This was supported by x-ray analysis data in which no crystalline peak of naproxen was found in the microparticles at a 4:1 polymer/ drug ratio. In view of the aforegoing discussion, it appears quite likely that the differential scanning calorimetry thermogram for papain-loaded submicron particles which contained $2.57 \%-2.80 \%$ of drug, (ie, the drug is present as an impurity in the polymer) also would not show any melting peak of papain, because the enzyme is dispersed in an amorphous state in an amorphous polymer. Powder x-ray diffraction for the papain-loaded submicron particles also did not show any peak for papain. Thus, the results of the present study are in accordance with already published results.

\section{Particle morphology}

Particles were analyzed by scanning electron microscopy to observe the morphology of the submicron particles. The particles made of Eudragit L100, Eudragit S100, and HPMCP containing papain were spherical and had smooth surfaces (Figure 8).

\section{Stability study}

Tables 3 and 4 show the results of the accelerated and longterm stability studies of the submicron particles and free papain formulations. The submicron particle formulations of $\mathrm{HS}_{4}, \mathrm{LS}_{4}$, and $\mathrm{SS}_{4}$ showed around $92 \%$ papain content on storage under accelerated conditions (ie, $40^{\circ} \mathrm{C}$ and $75 \%$ relative humidity) for six months, while the free papain formulation showed a $73 \%$ drug content (Table 3). However, $\mathrm{HS}_{4}, \mathrm{LS}_{4}$, and $\mathrm{SS}_{4}$, showed around $92 \%$ drug content when stored at $30^{\circ} \mathrm{C} / 65 \%$ relative humidity for 12 months against a $72.55 \%$ drug content for the free papain formulation. The results suggest improved stability of the enzyme on entrapment in polymer. On the basis of first order rate constants, the calculated $\mathrm{t}_{90}$ of $\mathrm{LS}_{4}, \mathrm{SS}_{4}$, and $\mathrm{HS}_{4}$ at $30^{\circ} \mathrm{C}$ and $65 \%$ relative humidity would be 495, 474, and 460 days, respectively (Table 4).

Table 3 Stability of free papain and optimised formulations of papain $\left(\mathrm{HS}_{4}, \mathrm{LS}_{4}\right.$ and $\left.\mathrm{SS}_{4}\right)$ under accelerated storage conditions $\left(40^{\circ} \mathrm{C} \pm\right.$ $\left.2^{\circ} \mathrm{C} / 75 \% \pm 5 \% \mathrm{RH}\right)$

\begin{tabular}{|c|c|c|c|c|c|}
\hline \multirow[t]{2}{*}{ Formulation code } & \multicolumn{4}{|c|}{ \% Papain activity remaining } & \multirow{2}{*}{$K_{\text {calc }}(\text { day })^{-1}$} \\
\hline & $0 \mathrm{M}$ & $1.5 \mathrm{M}$ & $3 M$ & $6 M$ & \\
\hline Papain & $100.00 \pm 2.26$ & $91.93 \pm 3.20$ & $82.78 \pm 3.19$ & $73.58 \pm 2.46$ & $1.71 \times 10^{-3}$ \\
\hline $\mathrm{HS}_{4}$ & $100.00 \pm 4.19$ & $97.86 \pm 3.13$ & $95.30 \pm 5.49$ & $92.09 \pm 3.12$ & $4.58 \times 10^{-4}$ \\
\hline $\mathrm{LS}_{4}$ & $100.00 \pm 3.77$ & $97.86 \pm 3.58$ & $95.79 \pm 3.21$ & $92.62 \pm 2.39$ & $4.26 \times 10^{-4}$ \\
\hline $\mathrm{SS}_{4}$ & $100.00 \pm 3.11$ & $97.37 \pm 3.65$ & $94.88 \pm 2.19$ & $92.13 \pm 1.98$ & $4.55 \times 10^{-4}$ \\
\hline
\end{tabular}

Note: *Values are mean \pm SE $(n=3)$.

Abbreviations: $\mathrm{M}$, months; $\mathrm{K}_{\text {calc }}$, calculated first-order degradation rate constant. 
Table 4 Stability of free papain and optimised formulations of papain $\left(\mathrm{HS}_{4}, \mathrm{LS}_{4}\right.$ and $\left.\mathrm{SS}_{4}\right)$ under room temperature storage $\left(30^{\circ} \mathrm{C} \pm\right.$ $\left.2^{\circ} \mathrm{C} / 65 \% \pm 5 \% \mathrm{RH}\right)$

\begin{tabular}{|c|c|c|c|c|c|c|c|c|}
\hline \multirow[t]{2}{*}{ Formulation code } & \multicolumn{5}{|c|}{ \% Papain activity remaining } & \multirow{2}{*}{$K_{\text {calc }}(\text { day })^{-1}$} & \multirow{2}{*}{$\mathbf{t}_{90}$ (Days) } & \multirow{2}{*}{$\begin{array}{l}\text { Int } t_{\text {calc }} \text { for } \\
2 \text { years }\end{array}$} \\
\hline & $O M$ & $3 M$ & $6 M$ & $9 M$ & $12 \mathrm{M}$ & & & \\
\hline Papain & $100.00 \pm 2.26$ & $94.56 \pm 2.32$ & $87.42 \pm 3.05$ & $79.21 \pm 2.87$ & $72.55 \pm 3.38$ & $8.79 \times 10^{-4}$ & 118.27 & 170.95 \\
\hline $\mathrm{HS}_{4}$ & $100.00 \pm 4.19$ & $98.22 \pm 2.86$ & $96.19 \pm 4.02$ & $94.59 \pm 3.28$ & $92.09 \pm 2.63$ & $2.26 \times 10^{-4}$ & 460.57 & 106.14 \\
\hline $\mathrm{LS}_{4}$ & $100.00 \pm 3.77$ & $98.35 \pm 3.50$ & $96.52 \pm 3.26$ & $94.45 \pm 4.09$ & $92.62 \pm 3.28$ & $2.10 \times 10^{-4}$ & 495.05 & 104.91 \\
\hline $\mathrm{SS}_{4}$ & $100.00 \pm 3.11$ & $98.13 \pm 3.49$ & $96.44 \pm 3.89$ & $94.19 \pm 3.68$ & $92.31 \pm 3.33$ & $2.19 \times 10^{-4}$ & 474.31 & 105.60 \\
\hline
\end{tabular}

Note: *Values are mean \pm SE $(\mathrm{n}=3)$.

Abbreviations: $\mathrm{M}$, months; $\mathrm{K}_{\text {calc }}$, calculated first order degradation rate constant; $\mathrm{t}_{90}$, time to reach $90 \%$ of initial drug concentration; Int $\mathrm{calc}_{\text {c }}$, calculated initial drug concentration for shelf life $\left(t_{90}\right)$ of 2 years.

The $\mathrm{K}_{\text {calc }} / \mathrm{t}_{90}$ values suggest that optimized formulations will not ensure a two-year shelf life $\left(\mathrm{t}_{90}\right)$ for the product and might need some overages, resulting in a need for a higher initial drug concentration. Thus, to ensure a two-year shelf-life, the $\mathrm{HS}_{4}, \mathrm{LS}_{4}$, and $\mathrm{SS}_{4}$ formulations would need 4.91\%-6.14\% overage (Table 4). The color of bulk papain powder, ie, nonentrapped papain, changed from pale buff to light brown. In contrast, the papain-loaded submicron particle formulations did not show any color change. Thus, the stability of papain entrapped in submicron particles was significantly improved in comparison with the bulk papain powder.

\section{Conclusion}

Papain was successfully encapsulated in enteric submicron particles by double emulsion solvent evaporation, optimizing the various formulation parameters in order to attain maximum encapsulation efficiency and a spherical shape, with an almost monodispersed particle size distribution and an optimum in vitro release profile. The release profiles for the formulations confirmed their gastroresistance, thus allowing $\mathrm{pH}$-dependent release of papain in the gastrointestinal tract. Eudragit L100 and HPMCP particles disintegrated and showed complete release of papain in the $\mathrm{pH}$ environment of the small intestine within four hours, whereas Eudragit S100 needs higher $\mathrm{pH}$ and a longer time for drug release. Thus, HPMCP, Eudragit L100, and Eudragit S100 particles have great potential as oral carriers for delivery of papain to the small and large intestines to facilitate digestion of proteins.

\section{Acknowledgments}

The authors are grateful to Banasthali Vidhyapith (Rajasthan, India) for providing their facilities for the undertaking of this research. Thanks are also due to Jubilant Organosys (Noida, India) for gifting the enteric polymers (HPMCP, Eudragit L100, and Eudragit S100) and Sophisticated Analytical Instrumentation Facility at All India Institute of Medical Sciences (New Delhi, India) for scanning electron microscopy.

\section{Disclosure}

The authors report no conflicts of interest in this work.

\section{References}

1. Layer P, Holtmann G. Pancreatic enzymes in chronic pancreatitis. Int J Pancreatol. 1994;15:1-11.

2. Jain S, Subramony C, Blanchard K, Petro M, Minocha A. Fibrosing colonopathy in a man with cystic fibrosis on pancreatic enzyme supplements. Ind J Gastroenterol. 2005;24:238.

3. Dobrilla G. Management of chronic pancreatitis. Focus on enzyme replacement therapy. Int J Pancreatol. 1989;5:17-29.

4. Nutriteck. Papain supplement enzyme health and nutrition product. Available from: http://www.nutriteck.com/papain.html. Accessed 15 August, 2011.

5. Arnon R. Papain. Methods Enzymol. 1970;19:226-244

6. Allemann E, Leroux J, Gurny R. Polymeric nano- and microparticles for the oral delivery of peptides and peptidomimetics. Adv Drug Deliv Rev. 1998;34:171-189.

7. Wu C, McGinity JW. Influence of an enteric polymer on drug release rates of theophylline from pellets coated with Eudragit ${ }^{\circledR}$ RS 30D. Pharm Dev Technol. 2003;8:103-110.

8. Asghar LF, Chandran S. Multiparticulate formulation approach to colon specific drug delivery: current perspectives. J Pharm Pharm Sci. 2006;9:327-338.

9. Chambliss WG. Enteric coatings. In: Swarbrick J, Boylan JC, editors. Encyclopedia of Pharmaceutical Technology. New York, NY: Marcel Dekker Inc; 1992.

10. Seitz JA, Mehta SP, Yeager JL. Tablet coating. In: Lachman L, Lieberman HA, Kanig JL, editors. The Theory and Practice of Industrial Pharmacy. Philadelphia, PA: Lea and Febiger; 1986.

11. Palmieri GF, Michelini S, Martino PD, Martelli S. Polymers with $\mathrm{pH}$ dependent solubility: Possibility of use in the formulation of gastroresistant and controlled release matrix tablets. Drug Dev Ind Pharm. 2000;26:837-845.

12. Kuhnelt $P$, Mundlos S, Adler G. Effect of pellet size of a pancreas enzyme preparation on duodenal lipolytic activity. Z Gastroenterol. 1991;29:417-421. German.

13. Stead RJ, Skypala I, Hodson ME, Batten JC. Enteric coated microspheres of pancreatin in the treatment of cystic fibrosis: comparison with a standard enteric coated preparation. Thorax. 1987;42: 533-537.

14. Bruno MJ, Borm JJ, Hoek FJ, et al. Gastric transit and pharmacodynamics of a two-millimeter enteric-coated pancreatin microsphere preparation in patients with chronic pancreatitis. Dig Dis Sci. 1998;43: 203-213.

15. Dai C, Wang B, Zhao H. Microencapsulation peptide and protein drugs delivery system. Collids Surf B Biointerfaces. 2005;41:117-120.

16. Lecaroz C, Gamazo C, Renedo MJ, Blanco-Prieto MJ. Biodegradable micro- and nanoparticles as long-term delivery vehicles for gentamicin. J Microencapsul. 2006;23:782-792. 
17. Zhang JX, Zhu KJ, Chen D. Preparation of bovine serum albumin loaded poly(D,L-lactic-co-glycolic acid) microspheres by a modified phase separation technique. J Microencapsul. 2005;22:117-126.

18. Chung TW, Tsai YL, Hsieh JH, Tsai WJ. Different ratios of lactide and glycolide in PLGA affect the surface property and protein delivery characteristics of the PLGA microspheres with hydrophobic additives. J Microencapsul. 2006;23:15-27.

19. Niwa T, Takeuchi H, Hino T, Kunou N, Kawashima Y. Preparations of biodegradable nanospheres of water-soluble and insoluble drugs with -lactide/glycolide copolymer by a novel spontaneous emulsification solvent diffusion method, and the drug release behavior. J Control Rel. 1993;25:89-98.

20. Lee JH, Park TG, Lee YB, Shin SC, Choi HK. Effect of adding nonvolatile oil as a core material for the floating microspheres prepared by emulsion solvent diffusion method. J Microencapsul. 2001;18: 65-75.

21. Laemmli UK. Cleavage of structural proteins during the assembly of the head of bacteriophage T4. Nature. 1970;227:680-685.

22. Zemser M, Friedman M, Katzhendler J, Greene LL, Minsky A, Gorinstein S. Relationship between functional properties and structure of ovalbumin. J Protein Chem. 1994;13:261-274.

23. Gaspar MM, Blanco D, Crus MEM, Alonso MJ. Formulation of L-asparaginase-loaded poly(lactide-co-glycolide) nanoparticles: influence of polymer properties on enzyme loading, activity and in vitro release. $J$ Control Rel. 1998;52:53-62.

24. Govender T, Stolnik S, Garnett MC, Illum L, Davis SS. PLGA nanoparticles prepared by nanoprecipitation: drug loading and release studies of water soluble drug. J Control Rel. 1999;57:171-185.

25. Jeffery H, Davis SS, O'Hagan DT. Preparation and characterization of poly(lactide-co-glycolide) microparticles, II: entrapment of a model protein using a (water in oil) in water emulsion solvent evaporation technique. Pharm Res. 1993;10:362-368.

26. Schlicher EJAM, Postma NS, Zuidema J, Talsma H, Hennink WE. Preparation and characterization of poly(D,L-lactic-co-glycolic acid) microspheres containing desferrioxamine. Int J Pharm. 1997; 153:235-245.

27. Li X, Deng X, Yuan M, et al. Investigation on process parameters involved in preparation of polylactide-poly(ethylene glycol) microspheres containing Leptospira interrogans antigens. Int J Pharm. 1999;178:245-255.

28. Yeh MK, Tung SM, Lu DW, Chiang CH. Formulation factors for preparing ocular biodegradable delivery system of 5-fluorouracil microparticles. J Microencapsul. 2001;18:507-519.
29. Re MI, Biscans B. Preparation of microparticles of ketoprofen with acrylic polymers by a quasi-emulsion solvent diffusion method. Powder Technol. 1999;101:120-133.

30. Cegnar M, Kos J, Kristl J. Cystatin incorporated in poly(lactide-coglycolide) nanoparticles: Development and fundamental studies on preservation of its activity. Eur J Pharm Sci. 2004;22:357-364.

31. Jain D, Majumdar DK, Panda AK. Insulin loaded Eudragit L100 microspheres for oral delivery: preliminary in vitro studies. J Biomater Appl. 2006;21:195-211.

32. Jain D, Panda AK, Majumdar DK. Eudragit S100 entrapped insulin microspheres for oral delivery. AAPS Pharm Sci Tech. 2005;6:E100-E107.

33. Sankalia MG, Mashru RC, Sankalia JM, Sutariya VB. Papain entrapment in alginate beads for stability improvement and site specific delivery: physicochemical characterization and factorial optimization using neural network modelling. AAPS Pharm Sci Tech. 2005;6:E209-E222.

34. Sankalia MG, Mashru RC, Sankalia JM, Sutariya VB. Physicochemical characterization of papain entrapped in ionotropically cross-linked kappa-carrageenan gel beads for stability improvement using Doehlert shell design. J Pharm Sci. 2006;95:1994-2012.

35. Murphy RJ, Pristinski D, Migler K, Douglas JF, Prabhu VM. Dynamic light scattering investigations of nanoparticle aggregation following a light-induced pH jump. J Chem Phys. 2010;132:194903-194906.

36. Hogan JE. Modified release coatings. In: Cole G, Aulton ME, Hogan J, editors. Pharmaceutical Coating Technology. Philadelphia, PA: Academic Press; 1995.

37. Meyer JH. Gastric emptying of ordinary food: effect of antrum on particle size. Am J Physiol Gastrointest Liver Physiol. 1980;239:G133-G135.

38. Bykov VA, Demina NB, Kataeva NN, Kemenova VA, Bagirova VL. Enzyme preparations used for the treatment of digestion insufficiency (a review). Pharm Chem J. 2000;34:3-7.

39. Handbook of Pharmaceutical Excipients. Polymethacrylates. London, UK: American Pharmaceutical Association and The Pharmaceutical Society of Great Britain, 1986.

40. Gibaldi M, Perrier D. Pharmacokinetics. 2nd ed. New York, NY: Marcel Dekker; 1982.

41. Shargel L, Yu A. Applied Biopharmaceutics and Pharmacokinetics. 4th ed. Stamford, CT: Appleton and Lange; 1999.

42. http://en.wikipedia.org/wiki/Fluorescence_spectroscopy.

43. Maghsoodi M. Physicochemical properties of naproxen-loaded microparticles prepared from Eudragit L100. AAPS Pharm Sci Tech. 2009; 10:120-128.
International Journal of Nanomedicine

\section{Publish your work in this journal}

The International Journal of Nanomedicine is an international, peerreviewed journal focusing on the application of nanotechnology in diagnostics, therapeutics, and drug delivery systems throughout the biomedical field. This journal is indexed on PubMed Central,



\section{Dovepress}

Journal Citation Reports/Science Edition, EMBase, Scopus and the Elsevier Bibliographic databases. The manuscript management system is completely online and includes a very quick and fair peer-review system, which is all easy to use. Visit http://www.dovepress.com/ testimonials.php to read real quotes from published authors. 